\title{
CRETACEOUS: EAST SIDE SACRAMENTO VALLEY, SHASTA AND BUTTE COUNTIES, CALIFORNIA ${ }^{1}$
}

\author{
W. P. POPENOL' \\ Pasadena, California
}

\section{ABSTRACT}

Isolated outcrops of Upper Cretaceous beds are found in the lower stream valleys, north, northeast, and east of Redding, Shasta County. The total thickness of the exposed beds aggregates 4,000 feet or more. Six well marked lithologic members, alternately predominantly sandstones and shales, may be recognized. The upper sandstones of Oak Run Valley, $2,500-3,000$ feet above the base of the section, are the probable correlatives of the base of the Cretaceous section at Chico Creek to miles south.

\section{INTRODUCTION}

This article presents a summary of the stratigraphy of the Upper Cretaceous beds cropping out north and east of the city of Redding, Shasta County, California, and suggests the probable age relations of these deposits to the Cretaceous deposits of Chico and Butte creeks on the east side of the Sacramento Valley near the city of Chico, in Butte County. This article represents a progress report, as the study of these Cretaceous beds is not yet complete. The investigation as a whole is the second of a series of projected studies of the faunas and stratigraphy of selected Upper Cretaceous sections of the Pacific Coast area. The results of the first study of this series dealing with the Cretaceous of southern California have recently been summarized in three articles. ${ }^{3}$

Investigation of the Cretaceous of the Redding region was begun in 1936 with support of a grant from the Penrose Bequest of the Geological Society of America, and since then has been pushed forward from time to time as other duties permitted. The detailed paleontology and stratigraphy of the Cretaceous of this region will be described in a report submitted to the Society when the work is completed.

\section{LOCATION}

Considerable areas of Cretaceous rocks are found cropping out in a fan-like series of isolated exposures lying north, northeast, and east of the city of Redding at the north end of the Sacramento Valley. The area is included in the Redding

${ }^{1}$ Read before the Pacific Section of the Association at Los Angeles, October I6, I941. Manuscript received, June $18,194^{2}$.

${ }^{2}$ Balch Graduate School of the Geological Sciences, California Institute of Technology.

The writer here acknowledges his appreciation for the help given in this work by the Geological Society of America. Further, he thanks the Society for permission to present this preliminary stratigraphic report through the medium of the Bulletin of the American Association of Petroleum Geologists.

${ }^{3}$ W. P. Popenoe, "Upper Cretaceous Mollusca from Southern California," Jour. Paleon., Vol. I I No. 5 (July, 1937).

- "The Trabuco and Baker Conglomerates of the Santa Ana Mountains," Jour. Geol., Vol. 49 , No. 7 (October-November, I941).

"Upper Cretaceous Formations and Faunas of Southern California," Bull. Amer. Assoc. Petrol. Geol., Vol. 25, No. 2 (February, I942). 
Quadrangle of the United States Geological Survey topographic atlas, and the areas of exposure of the Cretaceous rocks are indicated on the geologic map of the Redding Folio ( $U$. S. Geol. Survey Folio 138 ). The youngest surface rocks in the region are Tertiary land-laid sediments, and associated lavas, tuffs, ash beds, and other pyroclastics. The Cretaceous is exposed along the bottoms and lower slopes of the valleys of streams which have cut through the Tertiary cover into the older rocks below. The Cretaceous exposures are hence separated from one another by strips of Tertiary rocks that cap the interstream divides. The largest areas of outcrop, from north to south, are found in the valleys of Sand Creek, Little Cow Creek and its tributaries, Swede Creek, Oak Run, Clover Creek, Old Cow Creek, and South Cow Creek. The location of these exposures, their areal extent, their relationship to one another and to Redding and the distribution of the mappable members are indicated in Figure $\mathrm{I}$.

\section{STRUCTURE}

North of Clover Creek, the Cretaceous beds dip gently south or southeast at angles ordinarily of less than $10^{\circ}$, and in some places less than $5^{\circ}$. In upper Clover Creek, the dips are variable, and in places the strata are essentially flat. South of Clover Creek, the prevailing dips are westerly. In general, the Cretaceous beds appear to be warped into a broad, open, shallow syncline with northeast-trending axis approximately coinciding in position with upper Clover Creek valley. Considerable small-scale faulting is evident in places in the southern limb of the syncline.

\section{STRATIGRAPHY OF REDDING DISTRICT}

The Cretaceous rocks of the Redding district have a total thickness of at least 4,000 feet, and may be divided on a lithologic basis into six members. With one exception, the contacts between the members appear to be gradational and conformable. The lithologic units, in ascending order, are here described.

\section{MEMRBER I}

The basal member of the Redding Cretaceous section consists of about 700 feet of sandstone, with a basal conglomerate, not everywhere present, varying from Io to 40 feet in thickness. The base of the member is well exposed along the northern border of the Sand Flat and Little Cow Creek areas. The main areas of outcrop are found at Sand Flat and north of the Alturas-Redding highway (U. S. 299) in the Bellavista district. In the former region, the Cretaceous, nearly flat, rests on a basement of Devonian sediments and associated late Paleozoic igneous rocks. In the latter region, the Cretaceous beds rest with a profound angular unconformity on the Triassic Pit shale. The Cretaceous basal conglomerate is composed of well rounded and well cemented pebbles and cobbles including quartzites, cherts, shales, sandstones, and a considerable variety of both intrusive and effusive igneous rocks. The sandstones succeeding the basal conglomerates above are rather soft, coarse, brown and dominantly massive. In some 


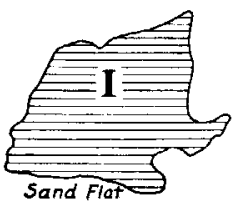

sand Flat

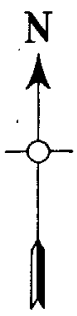

\section{LEGEND}

VI

Member VI. Dark-gray sandy shales with numerous

Member $\mathbf{Y}$. Coarse, arkosic gray sandstone alternating with finer-grained sandstone layers. Numerous ting with fick lower half of the member. Thickness: about 900 feet. Unconformable? on member below.

IV Member IV. Dark-gray sandy shales and shaly sandstones, with a few thin, coarse sandstone beds. Thickness: 1000 feet plus. Conformable on member below. IIV Member III. Coarse, cross-bedded gray sandstone, with feet plus. Conformable on member below. IIII Member II. Soft, gray, sandy clay shale with numerous

Member I. Coarse, brown arkosic cavernous weathering cross bedded sandstone below grading to finer-grained

erate $10-40$ faed theck above. Discontinuous canglom-

750 feet Unconformably overlies Triassic and Paleozoic sediments and igneous rocks.

\section{SCALE :}

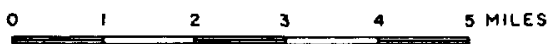

$\because:::$
MILLVILLE

$\theta$
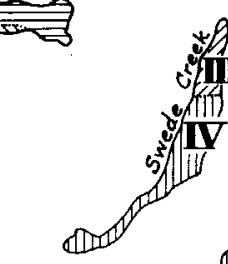

泮
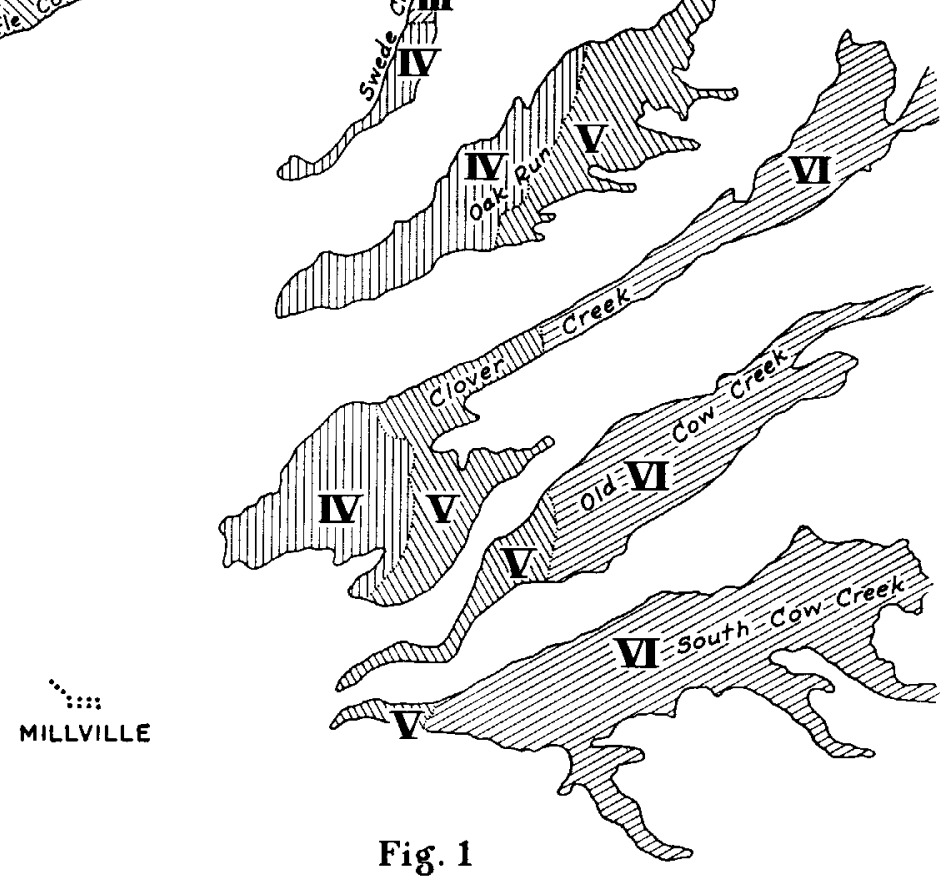

SKETCH MAP

OF A PART OF THE

REDDING QUADRANGLE

SHOWING THE PRINCIPAL CRETACEOUS EXPOSURES 
places they tend to show pronounced cross-bedding and cavernous weathering. Toward the top of the member, the sandstones become progressively thinner and more shaly, and pass gradationally into the member overlying. The strike of the beds approximates N. $70^{\circ} \mathrm{E}$. in most of the exposure, with dips of $5^{\circ}-10^{\circ} \mathrm{SE}$. The member is fossiliferous throughout, and has yielded a large fauna.

\section{MEMBER II}

The second member consists of 800 feet of silty to sandy dark gray shales with interbedded sandstones and some ironstone concretionary beds. Some fairly good exposures of this member are found in road cuts along the Redding-Alturas highway (C. S. 299), from I to 4 miles northeast of Bellavista. Bedding is indistinct and satisfactory determination of attitude is hard to get. The strike of the beds is about the same as that of the member underlying, and the dip ranges from $8^{\circ}$ to $12^{\circ} \mathrm{SE}$. The shales in many places are nearly barren, but in a number of localities they have yielded good faunas.

\section{MEMBER III}

The shales of Member II are overlain conformably by a series of greatly crossbedded, clean, hard, gray, arkosic sandstones that crop out along the course of Little Cow Creek in the region one mile northeast of Bellavista. These resemble the sandstones of Member I, but are finer-grained, somewhat harder, and gray rather than brown. This member is about 200 feet thick on Little Cow Creek. A similar sandstone containing a similar fauna crops out about 5 miles northeast in the upper valley of Swede Creek, and is believed to represent a continuation of the same member. The Swede Creek beds are likewise about 200 feet thick. The sandstones in both localities have yielded a fairly diversified and well preserved fauna.

\section{MEMBER IV}

The sandstones of Swede Creek grade upward into a series of dark sandy shales, and soft shaly sandstones interbedded with thin sandstone layers. These beds crop out downstream in Swede Creek for a distance of a mile or more. Similar beds crop out on the slopes of the north side of Oak Run valley. They have been included here with the Swede Creek shales of Member IV. The strike of these shales nearly coincides with the trend of the lava-covered Swede Creek-Oak Run divide, and an unknown thickness of the section is hence hidden here. If the beds hidden beneath the lava have the same strike and dip as the exposed beds on either side, they may represent a lost interval in the section of about I,O0o feet. The exposed shale beds in Swede Creek and Oak Run valleys aggregate about an additional r,ooo feet in thicknéss. The shales may be traced southwest across Clover Creek valley into Basin Hollow where they disappear beneath the stream gravels of the Millville plain. Member IV is sparingly fossiliferous, but has yielded a few good collections of fossils both on the Swede Creek and Oak Run sides. The faunas show a profound change from those of the Little Cow 


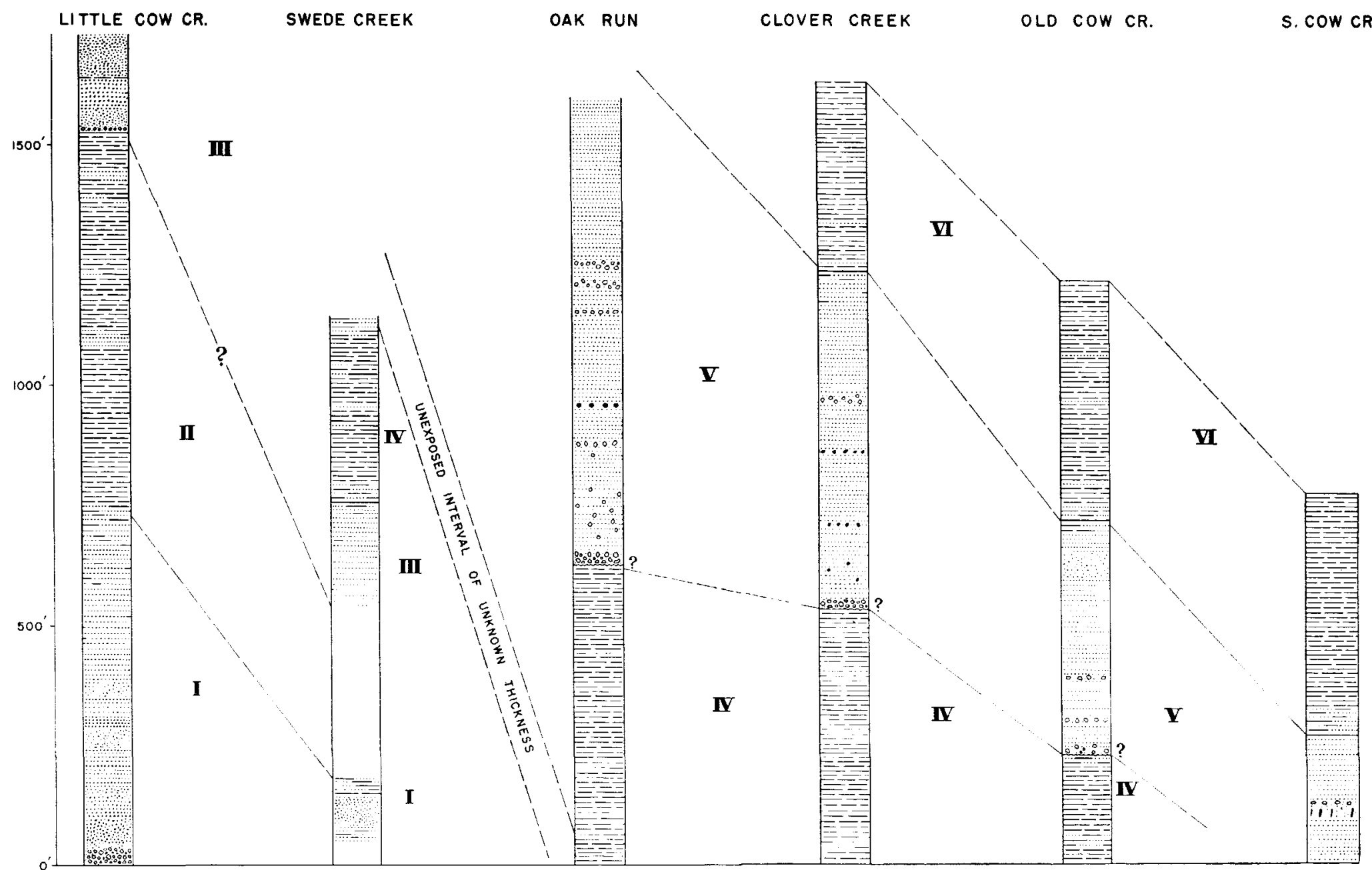

Fig. 2

GENERALIZED COLUMNAR SECTIONS CRETACEOUS OF THE REDDING QUADRANGLE SHOWING LOCAL DEVELOPMENT OF THE STRATIGRAPHIC MEMBERS 
Creek and upper Swede Creek localities, and introduce many species found abundantly in nearly all Cretaceous exposures south of Oak Run as far as Chico Creek and Pentz in Butte County.

\section{MEMBER V}

The shales of Member IV are succeeded above abruptly by a conglomerate and sandstone series at least 900 feet thick. The contact between the members is not well exposed but probably represents an unconformity. Besides the sharp lithologic break there is an apparent change of strike across the contact of $20^{\circ}$ $40^{\circ}$. The sandstones of Member $V$ are ordinarily coarse, arkosic, light gray, well cemented, and thick-bedded. The lower levels of the member likewise contain a number of widely spaced conglomerate beds Io-20 feet thick, and composed of smoothly rounded pebbles and cobbles of varied composition. Conglomerates are rare or absent in the upper part of the member, in which the sandstones are coarse, nearly massive, and in places greatly cross-bedded. The best exposures of this member are on the south side of Oak Run valley, where the lower conglomerates and sandstones determine a line of prominent hills. The member may be traced southwest from Oak Run valley across Clover Creek valley and Old Cow Creek to South Cow Creek. In the more northerly exposures, the beds of the member strike about N. $20^{\circ}$ E., and dip $5^{\circ}$ I $0^{\circ}$ SE. Farther south, the dips flatten. Coarse sandstones lithologically and faunally very similar to those of Oak Run crop out in the Burney Quadrangle on the east, in the upper valleys of Old Cow, South Cow, and Bear creeks, and dip west beneath the shales of the uppermost Member VI. 'These apparently represent the reappearance of Member $\mathrm{V}$ on the east limb of the syncline. They may be traced up Bear Creck valley to within 20 miles of Lassen National Park. In nearly every arca examined, the rocks of this member have yielded excellent collections of fossils.

\section{MEMBER VI}

Member VI consists of dark shale which crops out extensively in upper Clover Creek, Old Cow Creek, and South Cow Creek valleys. The shales are similar in appearance and lithology to those of members II and IV, except that they are somewhat better layered, and contain more sandstone. They show low and irregular dips in most places with considerable evidence of local distortion and small-scale faulting. The member is probably 500 feet thick in the Old Cow Creek region, and may be considerably more. The contact with the underlying sandstones of Member $V$ is not well exposed in most places, but in upper Old Cow Creek valley appears to be gradational with an alternation of fairly thick sandstone and shale beds throughout several hundred feet of section. The member has yielded a fairly good fauna mostly from localities in upper Clover Creek.

The columnar sections illustrating the described relationships of these members, and their developments in different areas, are shown in Figure 2. 'The thicknesses assigned to the members in the three right-hand columns are estimates and are probably not precise. 


\section{PROBABLE AGE EQUIVALENTS OF MEMBERS}

While some work has been done in determining the composition and the succession of the faunas in this and other California Cretaceous areas, any correlation attempted here must be provisional and tentative. The faunas of the Redding region can be grouped into two large sub-faunas. The older sub-fauna ranges from the base of the Cretaceous section to the basal beds of Member IV. Some of the most abundant and characteristic forms of this sub-fauna include Glycymeris pacificus Anderson, Gyrodes dowelli White, Pugnellus manubriatus Gabb, several species of small Scaphites, and a variety of keeled, Schloenbachialike ammonites. The sub-fauna may number 150 species, most of which are new. Nothing resembling this assemblage has been found on the east side of the Sacramento Valley south of Swede Creek; but it is present in the lower part of the Cretaceous section near Yreka in Siskiyou County, and in southern Oregon; near the base of the Cretaceous sections on Roaring River near Red Bluff, and along Putah Creek near Winters; in the Dark Hole Quadrangle southwest of Coalinga; and it is splendidly developed in the earlier Cretaceous beds of the Santa Ana Mountains in Orange County, southern California.

The upper sub-fauna at Redding appears in the shales of Member IV a few hundred feet above the base and ranges to the top of the section of this region. A few of the most abundant and characteristic forms of this assemblage include Glycymeris veatchii Gabb, Gyrodes expansa Gabb, Plectocion curvirostris (Gabb), and Cucullaea truncata? Gabb. Ammonites are rare with the exception of a species of Baculites which occurs in some localities in great numbers. The upper faunal assemblage may total 200 species. This faunal assemblage occurs likewise at Butte and Chico creeks in Butte County, in the lower 200 feet of the Cretaceous section. The rather sparse collections obtained from horizons $200-\mathrm{r}, 000$ feet above the base of the section at Chico Creek can not at present be definitely correlated with any part of the Redding section but may represent some part of Member VI. The faunas from horizons $1,000^{-2,000}$ feet above the base of the section at Chico Creek are characterized by the appearance of many species not found at Redding. For this reason, the upper $\mathrm{I}, 000$ feet, and perhaps the upper I, 800 feet of the Chico Creek section, are believed to be younger than any of the beds exposed in the Redding region. 